\title{
Bani Adam: Saadi Shirazi (AD 1184-1283/1291) and the concept of empathy
}

\author{
Sina Zarrintan • Fatemeh Ranjbar • Sina Aslanabadi • \\ Mohammad Hossein Zarrintan
}

Published online: 14 August 2014

(C) Springer-Verlag Berlin Heidelberg 2014

Abu-Muhammad Muslih al-Din bin Abdullah Shirazi, Saadi Shirazi was one of the prominent Iranian poets of the medieval period. He was born in 1184, and died in 1283 or 1291 in Shiraz, Iran [1]. Due to the Mongolian invasion of Iran, especially Khwarizm and Persia, Saadi was displaced by the ensuing conflict thus beginning a 30 year journey $[2,3]$. Saadi is recognized for the quality of his writings, and for the depth of his social and moral thoughts [3].

The Gulistan (Rose Garden) and Bustan (Orchard) of Saadi Shirazi are two classics of his works which provide the moral and ethical basis of reading for millions [3]. Saadi visited the centers of learning of the Islamic world and wrote poetry and literature which has not been surpassed [4]. He was educated in

\author{
S. Zarrintan \\ Department of General \& Vascular Surgery, Imam Reza Hospital, \\ Tabriz University of Medical Sciences, Tabriz, Iran \\ F. Ranjbar \\ Department of Psychiatry, Razi Hospital, Tabriz University of \\ Medical Sciences, Tabriz, Iran \\ F. Ranjbar \\ Clinical Psychiatry Research Center, Tabriz University of Medical \\ Sciences, Tabriz, Iran \\ S. Aslanabadi \\ Faculty of Medicine, Tabriz University of Medical Sciences, Tabriz, \\ Iran \\ M. H. Zarrintan \\ Department of Pharmaceutics, School of Pharmacy, Tabriz \\ University of Medical Sciences, Tabriz, Iran \\ S. Zarrintan $(\bowtie)$ \\ Department of General Surgery, Imam Reza Hospital, Golgasht St., \\ Tabriz 51664, Iran \\ e-mail: s.zarrintan@yahoo.com \\ S. Zarrintan \\ e-mail: zarrintans@tbzmed.ac.ir
}

Baghdad at the great college founded by Nizam al-Mulk (AD 1018-1092), the friend of Omar Khayyam (AD 1048-1131) and Minister of Court of the King [2]. Saadi's influence upon European literature is considerable. He is one of the groups whose writings gave substance to the Gesta Romanorum, source book for many Western legends and allegories. Scholars have traced many of Saadi's influences on European literature such as that of Germany $[2,3]$.

The Gulistan (Rose Garden) of Saadi contains traditional Persian texts, short stories, and short poems which encourage people to be kind to human beings and empathize with the feelings of their counterparts [3]. The Bustan (Orchard) is another collection of Saadi's works which consists of rhythmic Persian poems. Saadi's poems in Orchard and his short stories in Rose Garden emphasize on being kind and compassionate. Saadi considers empathy as an essential quality in humans' behavior [2, 3, 5]. He invites people to be peaceful and forgiving, considering that people would learn to be honest and change for the better if they were treated well.

In a poem from Rose Garden, Chapter 1: The manners of kings; 10th Story, Saadi invites human beings to consider themselves as parts of one body [6]. Saadi describes the concept of empathy in a meaningful and artistic sense that if one human being is suffered, it is like that all people in the world will be suffered. The original Persian text of this poem is illustrated in Fig. 1 and Cover picture. The English translation of this poem is as below [7]:

Humans (Children of Adam) are inherent parts (or more literally, limbs) of one body, and are from the same valuable essence (or more literally, gem) in their creation.

When the conditions of the time hurt one of these parts, other parts will be disturbed.

If you are indifferent about the misery of others,

it may not be appropriate to call you a human being. 
Fig. 1 And cover figure Abu-Muhammad Muslih al-Din bin Abdullah Shirazi known as Saadi Shirazi (A.D. 1184-1283/1291), prominent Iranian poet. Saadi Shirazi in a rose garden, from a manuscript of the Gulistan (Rose Garden) (Left); A Persian paining illustrating original Persian text of a well-known poem from Chapter 1, Story 10 of Gulistan by Saadi Shirazi known as "Bani Adam" which means the entire human beings (Right)

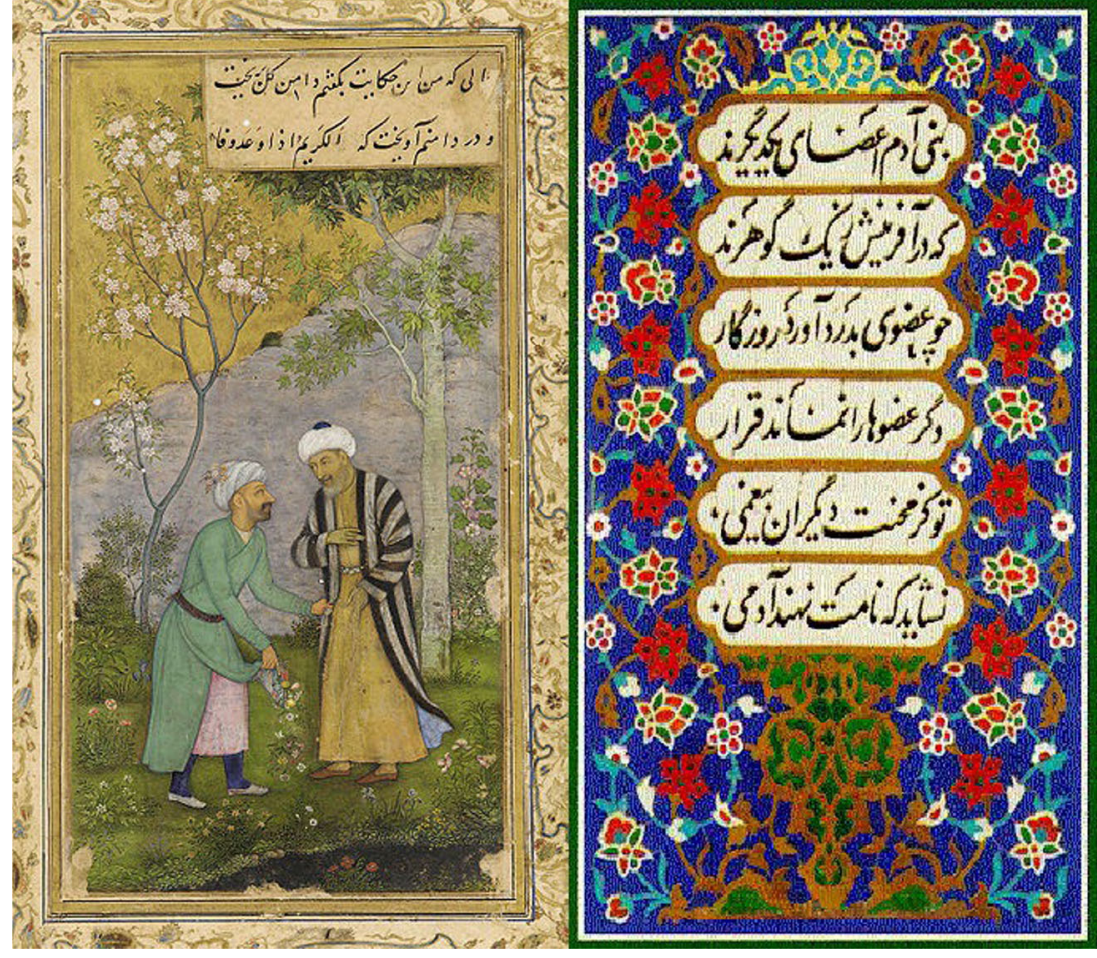

In this poem, Saadi addresses human beings as "Bani Adam". This poem is well-known as a declaration for peace and empathy by him. In addition, it is considered as a symbol of humanistic behavior. This poem is known as "Bani Adam" in Iranian and world literature. Saadi emphasizes that if someone does not deserve empathy in his or her manner, it would not be appropriate to consider him or her as a part of "Bani Adam". Saadi describes that if a limb of Bani Adam is injured (i.e., someone is suffered), the other limbs will be inflamed (i.e., the other people will feel anxious and will try to understand the injured one's feelings). This beautiful and ideal concept is one of the earliest and simplest descriptions of empathy from the thirteenth century medieval Iran. We are grateful to the Iranian prominent poet "Saadi" for his understanding of empathy and artistic description of this essential humanistic feeling.

Acknowledgements The authors would like to acknowledge Dr. Ali Tavakkoli from the Department of Surgery, Brigham and Women's Hospital, Harvard Medical School, Harvard, MA, USA for his useful comments during the preparation of this manuscript.
Conflict of interest The authors declare that they do not have any conflicts of interest.

\section{References}

1. Magill FN (1998) Dictionary of world biography: the middle ages. Routledge, New York, pp 806-807

2. Hanif N (2002) Biographical Encyclopaedia of Sufis: Central Asia and Middle East. Sarup \& Sons, New Delhi, pp 405-406

3. Arnold E (2007) The Gulistan of Sa'di: Sheikh Muslih-Uddin Sa'di Shirazi. Cosimo, Inc, New York, pp VI-IX

4. Vambery A (1998) Life and adventures of Armenius Vambery. J. Jetley, New Delhi, pp 125-127

5. Prastacos GP, Wang F, Soderquist KE (2012) Leadership through the classics: learning management and leadership from ancient east and west philosophy. Springer, New York, pp 197-199

6. Foroughi MA (1995) Gulistan-E-Saadi: Sheikh Muslih al-din Saadi Shirazi. Diba, Ghoghnous, Tehran, pp 34-35

7. Shirazi S. In: Wikipedia; the free encyclopedia. Retrieved July 24, 2014, from http://en.wikipedia.org/wiki/Saadi_Shirazi 